\title{
THE WELLCOME LABORATORY OF EXPERIMENTAL EMBRYOLOGY, UNIVERSITY COLLEGE OF NORTH WALES, BANGOR
}

\author{
By Prof. F. W. R. BRAMBELL, F.R.S.
}

\begin{abstract}
$\mathrm{O}^{\mathrm{N}}$ $\mathrm{N}$ March 5 the new postgraduate laboratory in the Department of Zoology was formally opened by Sir John Boyd. This is a single laboratory of 1,000 sq. ft., built as an extension of the top floor of the existing research block of the Department of Zoology at a cost of approximately $£ 10,000$, provided by the generosity of the Welleome Trust. The architects were Messrs. Sir Percy Thomas and Son, of Shrewsbury, and the builders were Messrs. Pochin (Contractors), Ltd., of Middlewich. The laboratory will provide for up to ten postgraduate research workers in experimental embryology. The whole block is devoted to postgraduate work and provides for about thirty-staff, students and ancillary technical staff. It includes the Agricultural Research Council's Unit of Embry ology under the direction of Prof. F. W. R. Brambell and nine postgraduate students working in related fields.

This group is interested primarily in problems of mammalian development, especially in the immunological relations of mother and young, born and unborn. The transmission of passive immunity from mother to young is a subject that bears widely on problems of fertility and on fœtal and neonatal survival, both in man and in domestic animals; it is also of fundamental significance. The Welleome Trust's gift has been made to extend the accommodation for workers in this field. The building is well equipped and provides for embryological, serological and immuno-chemical techniques. The next largest research group is concerned with ecological problems of freshwater and terrestrial animals. Others are working on the physiology of marine sponges, on the biophysies of the swimbladder of fishes, on cytochemistry and the genetics of bird populations. The geographical situation of Bangor, with the natural facilities which the environment of sea, mountains and freshwater provide, is particularly favourable for animal biology. The resources of
\end{abstract}

the Department of Zoology for research in these fields are greatly strengthened by the presence of the Marine Science Laboratories of the College at Menai Bridge, only two miles away, and by the neighbouring Department of Agricultural and Forest Zoology.

A Department of Biology was established when the College opened in 1884. In 1895 this was split into separate Departments of Botany and Zoology and Prof. P. J. White was appointed to the chair of zoology, a position which he occupied until his death in 1929. During his long tenure of the chair, he built up the splendid collections that, with some additions, constitute the present Museum of Zoology. Prof. F. W. R. Brambell was appointed to succeed him in 1930, the title being changed to the Lloyd Roberts chair of zoology. The main building, which provides for all the undergraduate teaching and houses some of the staff and the administration, has been occupied since 1926. It was shared by the Departments of Botany and Zoology until 1955, when Zoology occupied the whole block, after it had been refitted and modernized. The research block was opened in 1953, extended in 1960, and is now complete. The animal houses of the department were built in 1955 .

The undergraduate accommodation has been full to capacity with more than 130 students for the past five years, and despite the very great pressure for entry to the honours courses in zoology, it is not possible to increase the undergraduate accommodation further until the plan to replace the main building has been put into effect. The present extension to the research block provides a welcome increase in the accommodation for postgraduates, now numbering fifteen. A postgraduate instructional course in embryology and mammalian reproduction leading to the degree of M.Se. has been started this session.

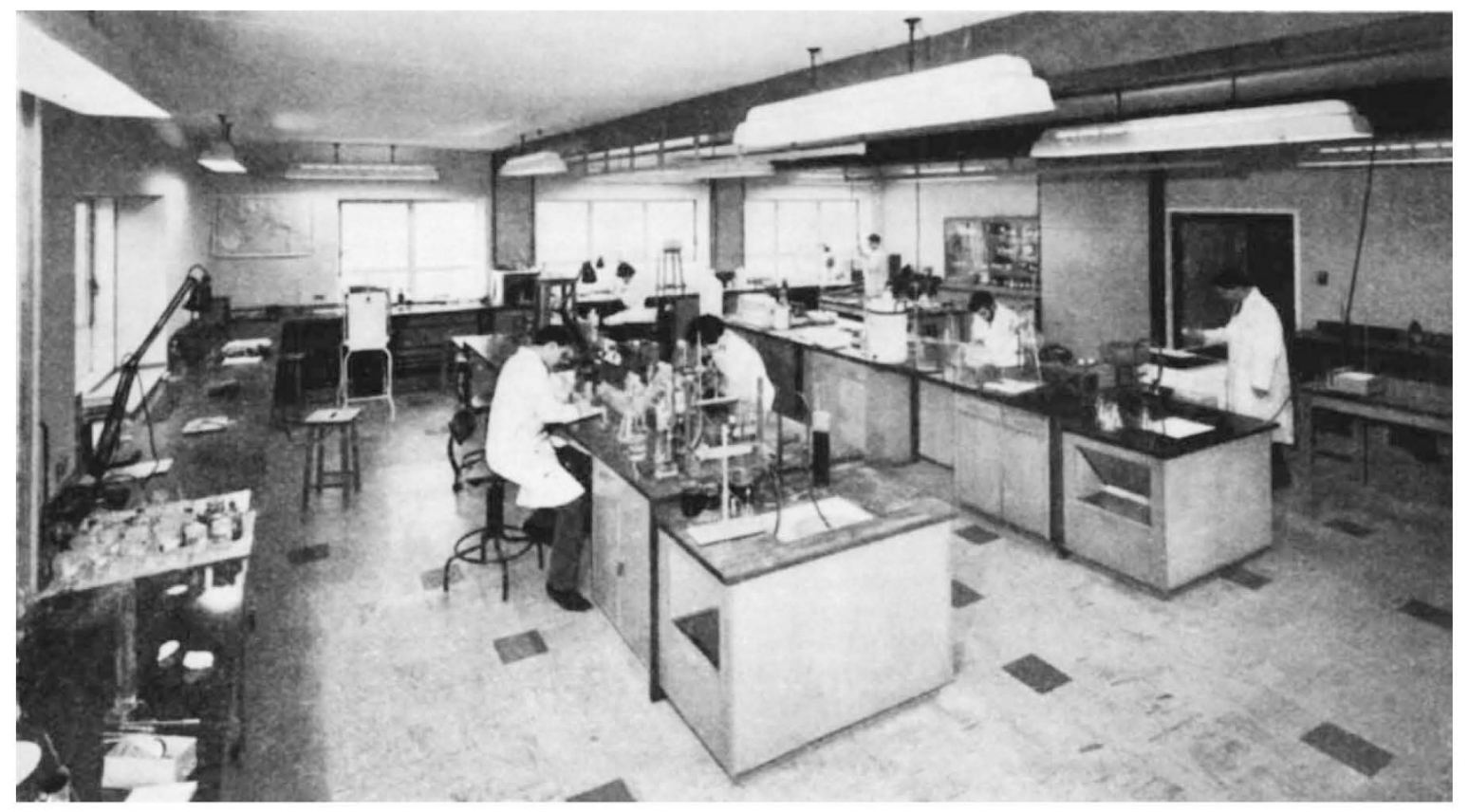

Fig. 1. The Welleome Laboratory of Experimental Embryology, University College of North Wales, Bangor 